\title{
Bird-epiphyte interactions in three Atlantic Forest environments in southeastern Brazil
}

\author{
Rafael Ferreira Boechat ${ }^{1}$, Bianca Ferreira da Silva ${ }^{1} \&$ André Felippe Nunes-Freitas ${ }^{1,2}$ \\ ${ }^{1}$ Laboratório de Ecologia Florestal e Biologia Vegetal, Departamento de Ciências Ambientais, Instituto de Florestas, Universidade Federal Rural do \\ Rio de Janeiro, Seropédica, RJ, Brazil. \\ 2 Corresponding author: afnfreitas@gmail.com
}

Received on 17 September 2018. Accepted on 03 May 2019.

\begin{abstract}
Epiphytes reach up to $67 \%$ of the total plant species richness in some tropical areas and act as diverse food resources that can be crucial in times of food scarcity. The avifauna assists in their reproduction, either through pollination or seed dispersal, thus creating a vast interaction spectrum between both communities within a continuous ecological process. Few scientific studies concerning avian and epiphytic community interactions are available and not much is known on their specific relationships. However, their absence can change existing ecological processes in habitats. With this in mind, a study undertaken at the Reserva Ecológica do Guapiaçu, Cachoeiras de Macacu, RJ analyzed bird and epiphytic interactions in three different environments: forest, fragmented forest and pastureland. The aim was to study how these interactions can vary according to their degree of conservation and successional stage. Three observation points were marked in a forest, nine points in forest fragments and ten observation points in the pastureland, thus providing a total of 1056 observation hours. As a result, 643 avian and epiphytic interactions were registered. We tested differences in the number of interactions between the areas. The initial hypothesis was that the largest number of registered interactions would occur in the preserved forest given its preserved state and existing biodiversity; however, the pasture area presented the highest number and variety of interactions. Most of the birds observed in the different habitats presented a high interaction in pasture areas where resource availability is reduced, making epiphytes an important food supply. Epiphytes permit a valuable network of interactions by attracting a high diversity of birds, especially those that disperse fruit or pollinate flowers, illustrating their importance within a degraded environment.
\end{abstract}

KEY-WORDS: bird diversity, bird interactions, conservation areas, mutualistic interactions, vascular epiphytes.

\section{INTRODUCTION}

Epiphyte plants comprise $33-50 \%$ of the total vascular flora of tropical forests and can reach up to $67 \%$ of the total plant species richness in some areas (Benzing 1990). This flora provides a variety of resources that are of great importance to birds, including maintaining or expanding bird diversity in Neotropical forests (Nadkarni \& Matelson 1989), considering that epiphytes provide different resources such as nectar, fruits, seeds and water, as well as nesting material and nesting sites (Nadkarni \& Matelson 1989, Sillet 1994). In some cases, such as in tank bromeliads, the morphology and imbricated arrangement of the leaves allow water and organic matter accumulation (Benzing 1990, Rocha et al. 2004), where invertebrates and small vertebrates that constitute prey for various species of birds live (Richards 1996, Rocha et al. 2004). In this way, epiphytes can provide resources during periods of scarcity, temporarily becoming an important source for different organisms (Nadkarni \& Matelson 1989, Rocha et al. 2004, Cestari \& Pizo 2008).

The interactions between birds and epiphytic plants can occur in different ways. Hummingbirds, as nectarivorous birds, commonly interact with species of epiphytic plants, especially bromeliads (Canela \& Sazima 2003, Piacentini \& Varassin 2007). However, insectivorous birds can also forage in epiphytes, using different tactics and parts of the epiphytes to obtain their resources (Sillet 1994). Frugivorous bird species are also able to consume fruits and seeds of epiphytes, not only being able to disperse them in trees of forest remnants, but also in deforested areas due to the use of isolated trees (Sheldon \& Nadkarni 2013).

The presence of epiphytes contributes to increase bird diversity in both conserved and anthropogenic areas (Nadkarni \& Matelson 1989, Cruz-Angón \& Greenberg 2005). So, it is an important aspect in Atlantic Forest, considering this is the more devastated and reduced Brazilian biome. However, few specific studies have been carried out to understand the relationships between epiphyte and bird communities in this biome. There are many studies of interactions between birds and plants in general, including epiphytes. These studies focus on guilds generally, such as frugivorous birds or 
hummingbirds (nectarivores) (Fadini \& Marco-Jr. 2004, Ikuta \& Martins 2013). Thus, they did not cover the entire bird community. Other studies focus on plant species and did not cover the entire plant community (for a review, see Cestari 2009). In Brazil, Cestari \& Pizo (2008) and Pizo (1994) carried out further studies with a focus on understanding the role of the avian-epiphytic interactions.

The Atlantic Forest is considered one of the 34 biodiversity hotspots worldwide and is characterized by a high degree of fragmentation and anthropogenic actions (Myers et al. 2000). Anthropogenic actions affect the mutualistic interactions between fauna and flora, such as pollination and dispersion (Groombridge 1992). According to Jordano et al. (2006), efforts by the scientific community to investigate the effects of environmental degradation on ecological interactions did not begin until the 1990's. In a recent study, Hasui et al. (2017) found 832 bird species in Atlantic Forest and they suggest that this number reinforces the critical situation of taxa in this biome.

Thus, studies aimed at understanding the relationships between birds and epiphytes are necessary, especially in face of anthropic alterations such as the removal of vegetation cover and forest fragmentation, which can exert considerable disturbances to the interactions, and consequently lead to losses in interactions and the simplification of bird and epiphyte communities in tropical forests. The objective of the present study was to investigate the use of epiphytes by birds in three different environments within a continuum between preserved and degraded in an area of Atlantic Forest in order to answer the following questions: (1) Which bird species use epiphytes and how often do the interactions occur in the different environments studied? (2) What are the epiphytes and resources used? Our hypothesis is that native areas have higher interactions between birds and epiphytes considering that native areas have more diversity of birds and epiphytes.

\section{METHODS}

\section{Study site}

We conducted the study in the Guapiaçu Ecological Reserve (REGUA; 7380 ha; $22^{\circ} 25, S ; 42^{\circ} 44, W$ ) in the agricultural community of Guapiaçu, Cachoeiras de Macacu, Rio de Janeiro state, Brazil. The area belongs to a non-governmental organization (NGO) created in 1996 to protect the area from deforestation, hunting and resource exploitation. The reserve is located in the Atlantic Forest and has an area bordering several Conservation Units of the Rio Serrano Central Region, such as the Três
Picos State Park and the Serra dos Órgãos State Park, with large old-growth forest remnants.

The area presents Dense Ombrophilous Forest (DOF) formations with different altitudes, with flat topography to cliffs and the presence of rocky outcrops (IBGE 2009). The climate of the region is tropical with rainy summers and dry winters, in which December and January are the rainiest months and June and July are the driest. The lower altitudinal areas have a history of occupation, alternative land use and pasture use of about a century. Agricultural practices were only interrupted in 2004 and these areas were then integrated to the Reserve (Azevedo 2012). Thus, REGUA covers large areas of preserved forest, pasture areas and forest fragments leftover from previously existing activities

\section{Data collection}

We selected three areas in the different environments found in the study area: continuous forest, forest fragments and pasture. We selected phorophytes with high epiphyte density. In the forest area, we selected three phorophytes as observation points and observed a $10 \mathrm{~m}$ radius in the environment. We also selected three fragment areas, and in each one we selected three phorophytes as the observation point, totaling nine phorophytes. In the pasture area, we selected 10 isolated trees that served as observation points and whose canopies did not connect to other trees. In all areas, the phorophytes were at least $50 \mathrm{~m}$ apart.

Observations were done monthly between February 2012 and October 2013. Each phorophyte was observed monthly for a period of $2 \mathrm{~h}$. Observations were made between 6:00 h to 18:00 h. We observed each phorophyte for a total of $42 \mathrm{~h}$ throughout the study. We randomize the observation order of the points monthly in order to avoid trends in the records. We recorded the bird species that interacted with the epiphyte according to Sigrist (2009), identifying the resources extracted by the birds. The bird species were classified according to their diet categories (insectivorous, frugivorous and nectarivorous), based on both personal observations as well as in the literature (Cestari \& Pizo 2008).

Considering that the availability of the epiphytes affects the number of interactions, we evaluated the density by the method of Sillet (1994). The phorophyte was divided into sampling units of about $1 \mathrm{~m}$ from the ground level to the tree canopy. Each epiphyte species was recorded at each interval. The availability of each species of epiphytes was:

$$
\text { DGep }=\sum \text { Gep/Ncil }
$$

where DGep is the availability of each species 
epiphytes, $\Sigma \mathrm{Gep}$ is the sum of the total of individuals of this species and $N_{c i l}$ is the total of imaginary cylinders in which the species occurred. We measured the density only once throughout the study for each species separated by the areas where they occur.

\section{Data analysis}

We performed a generalized linear model (glm) using Poisson family with number of interactions as the response variable and area, epiphyte species and epiphyte density as predictor variables. After this analysis, we performed multiple comparisons using "agricolae" package. All analysis were performed using $\mathrm{R}$ software version 3.5.2.

\section{RESULTS}

We recorded 644 events of interactions between 17 bird species and six epiphytes in the three studied areas (Table 1; Fig. 1). Most of the interactions were recorded in the pasture areas ( $n=566$ interaction events, $87.9 \%$ of the total), while there were fewer interactions in the fragments $(n=63$ events, 9.8\%) and in the continuous forest $(n$ $=15,2.3 \%)$. Area affect interactions with pasture area containing the largest record of interactions $(P<0.001$, $d f=2$; Fig. 2). Moreover, density and species identity also affected the number of interactions $\left(P<0.001, d f_{\text {den }}=1\right.$, $d f_{\text {spe }}=5$; Table 2).

The most representative bird families were Trochilidae, Thraupidae and Tyrannidae, which together represented $64.7 \%$ of the bird species observed. Tyrannidae presented the highest number of interactions $(n=239$, $37.2 \%$ of the total), followed by Thraupidae ( $n=189$; $29.4 \%)$, Trochilidae $(n=110,17.1 \%)$ and Fringillidae $(n$ $=92,14.3 \%)$. The other families represented only $2 \%$ of the interactions, with less than 10 interactions each.

The only bird recorded in interactions in all three analyzed areas was Amazilia fimbriata (Gmelin, 1788). The species with the highest number of interactions were Pitangussulphuratus (Linnaeus, 1766) ( $n=97$ interactions, $15.1 \%$ of the total), Euphonia chlorotica (Linnaeus, 1766) ( $n=92$ interactions, $14.3 \%)$ and Tyrannus melancholicus Vieillot, 1819 ( $n=80$ interactions, $12.4 \%$ of the total). The registered birds mainly have generalist eating habits $(n=5$ species, $29.5 \%)$ (Table 1$)$. Exclusive frugivores, insectivores and nectarivores contributed with the same number of species ( $n=4$ species, $23.5 \%$ each group; Table 1).

The birds used four Bromeliaceae and two Cactaceae epiphytic species. Aechmea nudicaulis (L.) Griseb. had the highest number of recorded interactions (4.6 \pm 5.5, 46.4\%) and was different of Rhipsallis baccifera (JS Muell.). Rhipsallis elliptica (G. Lindb. ex K. Schum.) had the lowest number of interactions and was different of all other epiphytes $(0.5 \pm 0.6,0.01 \%$, Fig. 3$)$. Another eight epiphytes species were present in the environments and were not used by birds, including species of Bromeliaceae, Araceae, Piperaceae and pteridophytes, among others.

Foraging was the most frequent use of epiphytes in all areas and included flower visiting, seed foraging and arthropod predation (forest $=66.7 \%$, fragment $=85.5 \%$, pasture $=43.3 \%)($ Fig. 2). Flower visiting was the most common foraging type in the three areas and the only one observed in the continuous forest (Fig. 4). Regarding predation, the birds pick up arthropods living in the plant parts (bromeliad tank and dry parts).

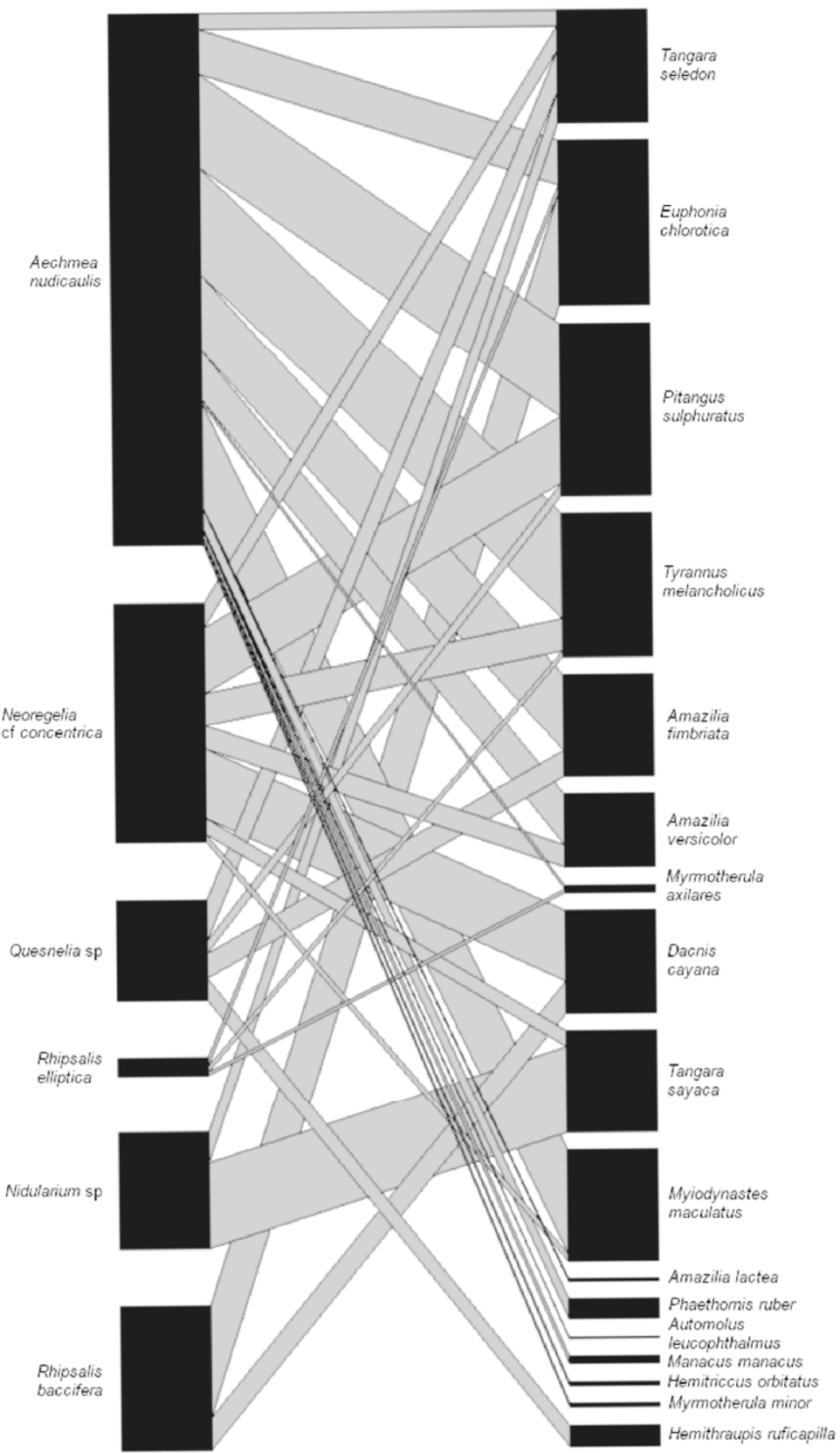

Figure 1. Interaction network between birds (right) e epiphytes (left) in Rio de Janeiro state, Brazil. The bar thickness is proportional to the total interactions performed by the species. 
Table 1. Bird species interacting with epiphytes in the three study environments, with information on the areas where the interactions occurred and the diet category of the species, in Rio de Janeiro state, Brazil. Areas: Fo $=$ forest, $\mathrm{Fr}=$ fragment, $\mathrm{Pa}=$ pasture. Diet: $\mathrm{N}=$ nectarivorous, $\mathrm{F}=$ frugivorous, $\mathrm{I}=$ insectivorous.

\begin{tabular}{|c|c|c|}
\hline Bird species & Areas & Diet \\
\hline \multicolumn{3}{|l|}{ Trochilidae } \\
\hline Amazilia fimbriata (Gmelin, 1788) & Fo; Fr; Pa & $\mathrm{N}$ \\
\hline Amazilia lactea (Lesson, 1832) & Fr & $\mathrm{N}$ \\
\hline Amazilia versicolor (Vieillot, 1818) & $\mathrm{Fr} ; \mathrm{Pa}$ & $\mathrm{N}$ \\
\hline Phaethornis ruber (Linnaeus, 1758) & Fo; Fr & $\mathrm{N}$ \\
\hline \multicolumn{3}{|l|}{ Fringillidae } \\
\hline Euphonia chlorotica (Linnaeus, 1766) & $\mathrm{Fr} ; \mathrm{Pa}$ & $\mathrm{F}$ \\
\hline \multicolumn{3}{|l|}{ Furnariidae } \\
\hline Automolus leucophthalmus (Wied, 1821) & Fo & I \\
\hline \multicolumn{3}{|l|}{ Pipridae } \\
\hline Manacus manacus (Linnaeus, 1766) & Fo; Fr & $\mathrm{F}$ \\
\hline \multicolumn{3}{|l|}{ Rhynchocyclidae } \\
\hline Hemitriccus orbitatus (Wied, 1831) & $\mathrm{Fr}$ & I \\
\hline \multicolumn{3}{|l|}{ Thamnophilidae } \\
\hline Myrmotherula axilares (Vieillot, 1817) & $\mathrm{Fr}$ & $\mathrm{I}$ \\
\hline Myrmotherula minor Salvadori, 1864 & $\mathrm{Fr}$ & $\mathrm{I}$ \\
\hline \multicolumn{3}{|l|}{ Thraupidae } \\
\hline Dacnis cayana (Linnaeus, 1766) & $\mathrm{Pa}$ & $\mathrm{N} / \mathrm{F} / \mathrm{I}$ \\
\hline Hemithraupis ruficapilla (Vieillot, 1818) & $\mathrm{Pa}$ & $\mathrm{F}$ \\
\hline Tangara seledon (Statius Muller, 1776) & Fo; $\mathrm{Pa}$ & $\mathrm{F}$ \\
\hline Tangara sayaca (Linnaeus, 1766) & $\mathrm{Pa}$ & $\mathrm{N} / \mathrm{F} / \mathrm{I}$ \\
\hline \multicolumn{3}{|l|}{ Tyrannidae } \\
\hline Myiodynastes maculatus (Statius Muller, 1776) & $\mathrm{Pa}$ & $\mathrm{I} / \mathrm{F}$ \\
\hline Pitangus sulphuratus (Linnaeus, 1766) & $\mathrm{Pa}$ & $\mathrm{I} / \mathrm{F}$ \\
\hline Tyrannus melancholicus Vieillot, 1819 & Fr; Pa & $\mathrm{I} / \mathrm{F}$ \\
\hline
\end{tabular}

Table 2. Density of epiphyte species in the three study environments (forest, fragments and pasture) in Rio de Janeiro state, Brazil.

\begin{tabular}{lccc}
\hline Epiphyte species & Forest & Fragments & Pasture \\
\hline Aechmea nudicaulis & 15.0 & 23.3 & 66.0 \\
Neoregelia cf. concentrica & 20.0 & 29.8 & 29.0 \\
Nidularium sp. & 0.0 & 0.0 & 9.0 \\
Quesnelia sp. & 0.0 & 0.0 & 8.5 \\
Rhipsalis baccifera & 8.3 & 21.6 & 57.5 \\
Rhipsalis elliptica & 10.0 & 33.2 & 19.0 \\
\hline
\end{tabular}

In addition to the Trochilidae species, Dacnis cayana (Linnaeus, 1766) and Tangara sayaca (Linnaeus, 1766) also visited flowers of the bromeliad species. Rhipsalis baccifera and $A$. nudicaulis epiphytes had their seeds forraged by species of E. clorotica, Myiodynastes maculatus (Statius Muller, 1776) and T. melancholicus. Other uses of the epiphytes by the birds were to collect material for nests, baths and perches. The only epiphytes used for bathing were $A$. nudicaulis and $N$. concentrica. Many birds accessed the interior of the epiphytes, but it was not possible to identify the resources they used (forest $=$ $13.3 \%$, fragment $=9.7 \%$, pasture $=38.9 \%$ ). 


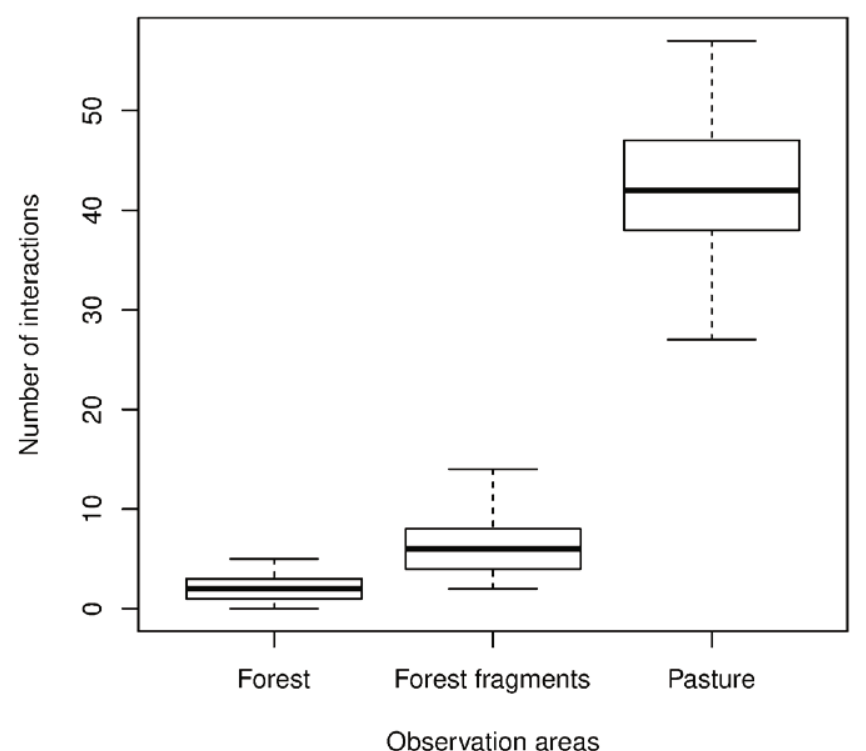

Figure 2. Number of records of interactions between birds and epiphytes in areas of forest, forest fragments and pasture in the study conducted at Guapiaçu Ecological Reserve, Brazil, over 21 months.

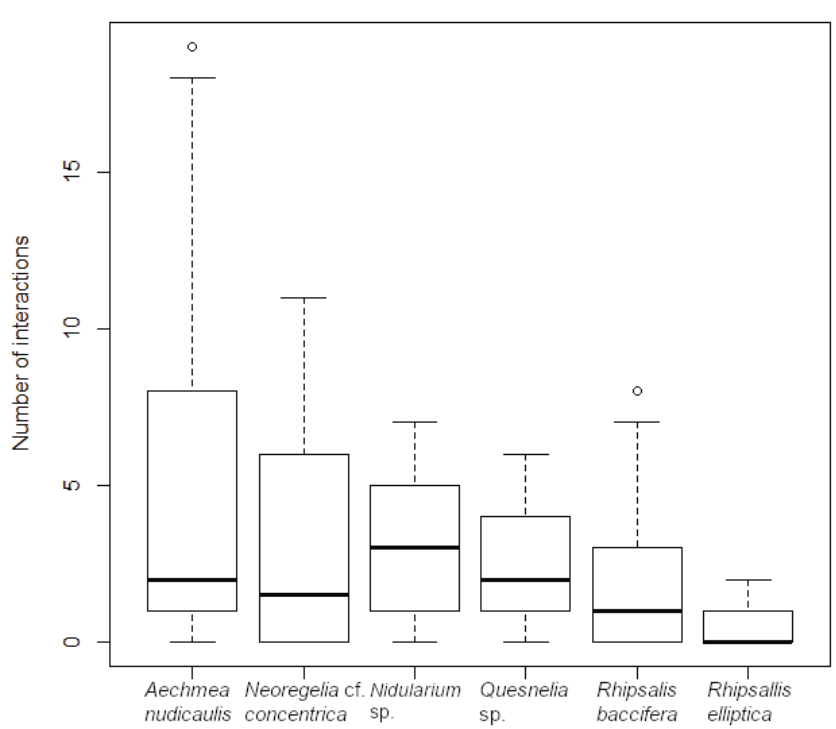

Figure 3. Number of records of interactions between birds and the different epiphytes species in the study conducted at Guapiaçu Ecological Reserve, Brazil, over 21 months.

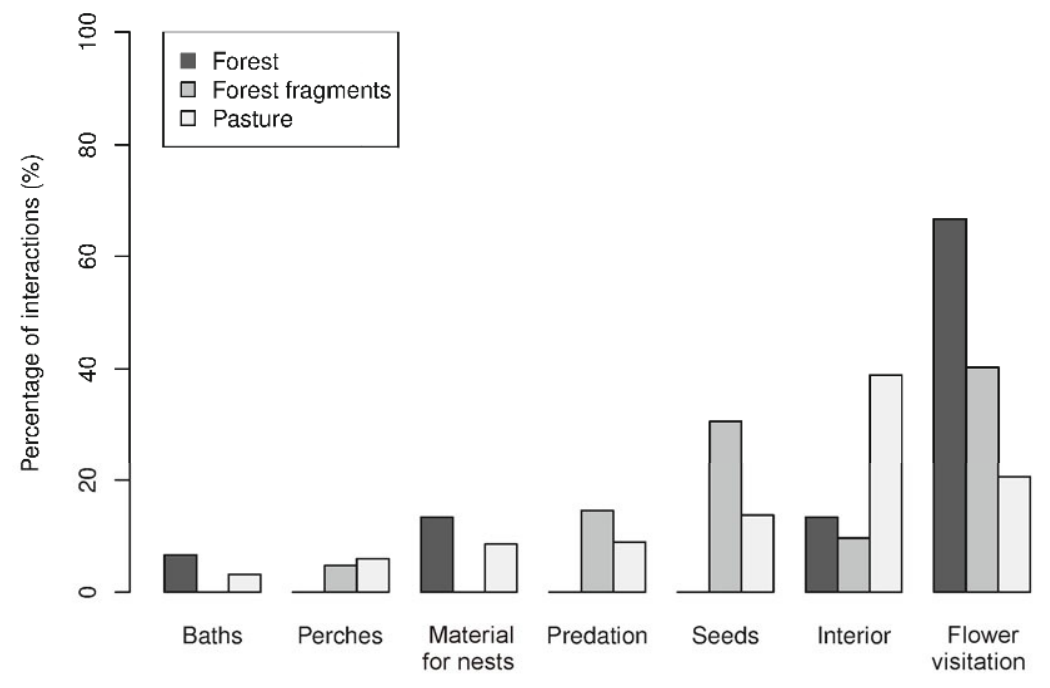

Figure 4. Absolute frequency of the different uses of the epiphytes by birds in the studied forest fragments and pasture areas at Guapiaçu Ecological Reserve, Brazil.

\section{DISCUSSION}

In the present study, we verified that the interactions mainly occurred in the pasture areas and that the birds had more interactions with a few epiphyte species. These epiphyte species offer varied resources and they occur densely in open areas like pastures. In addition, despite the high number of bird species performing interactions, most interactions were only performed by three species (P. sulphuratus, E. chlorotica and T. melancholicus), which accounted for approximately $42 \%$ of the interactions.
These three species are frugivorous and/or insectivorous and are generalists in occupying habitat, which favoring their occupation at different studied areas.

The pasture trees in our study showed a high abundance of epiphytes representing an important source of resources. The density affected number of interactions and high values in pasture can explain the greater number of interactions recorded in this environment. Thus, the abundance of epiphytes and the availability of resources offered by them will influence the use by birds (Sheldon \& Nadkarni 2013). Isolated trees in altered environments 
play a key role for biodiversity (Manning et al. 2006, Gibbons et al. 2008, Moga et al. 2016, Prevedello et al. 2018), serving as a shelter area and a source of resources for different animals, including birds (Pizo \& Santos 2011, Barth et al. 2015). Moreover, these trees serve as the focal point for regeneration of disturbed landscapes (Schlawin \& Zahawi 2008, Sandor \& Chazdon 2014, Zwiener et al. 2014, Derroire et al. 2016), connecting habitat patches like "steppingstones" (e.g., Prevedello et al. 2018) and as a colonization site by different epiphyte species (Poltz \& Zotz 2011).

Vascular epiphytes occurring in isolated trees increase the availability of resources in isolated trees, providing additional resources for birds such as water, forage, material and nesting sites (Nadkarni \& Matelson 1989, Sillett 1994, Rocha et al. 2004), having an important role in maintaining populations of bird species. This role becomes important in altered sites such as pastures or forest fragments. Epiphytes function as microhabitats that reduce the temperature, facilitating the permanence and use of these environments by the animals and offering resources throughout the year (Scheffers et al. 2014).

More preserved environments such as continuous forests can offer a great variety of resources coming from the different strata or synusiae of the forest (Wheelwright et al. 1984, Nadkarni \& Matelson 1989). Thus, the epiphytes would be less important in environments with greater availability of resources, such as forests (Wheelwright et al. 1984). This explain the lower number of interactions in this habitat.

Aechmea nudicaulis showed the highest frequency of interactions with birds and the greatest variety of exploited resources (flowers, seeds, invertebrates, bathing water, nest material and perches). Due to their availability and concentric arrangement of the leaves, the plants of this family can offer a greater variety of resources for use by birds (Rocha et al. 2004, Cestari \& Pizo 2008). Thus, they can accumulate water and organic matter in the bases of their leaves, creating a microcosm that allows colonization by invertebrate and vertebrate animals (Nadkarni \& Matelson 1989), which can be used as resources by birds.

Among the recorded avifauna, A. fimbriata was present in all three environments, being a very well represented species in open areas and in forest edges, and with territorial behavior (Antas 2004). Hummingbirds are effective pollinators and their high frequency was fomented by higher availability of hummingbirdpollinated flowers in all sites (all studied bromeliads). For example, A. nudicaulis (Bromeliaceae), which has longer flowers and concentrated nectar, are frequently used by these birds, especially A. fimbriata (Canela \& Sazima 2003). Hummingbirds increase the reproductive success rates of epiphytes by pollination, including in degraded environments (Martinelli 1997).
In a review of the use of epiphytes by birds in Brazil, Cestari (2009) recorded 42 studies that included interactions between these groups. According to the revised studies, 112 bird species were recorded interacting with 97 species of epiphytes. Our study included six bird species that did not appear in the survey conducted by Cestari (2009): Hemitriccus orbitatus (Wied, 1831), Myrmotherula axillaris (Vieillot, 1817), Manacus manacus (Linnaeus, 1766), T. sayaca, T. melancholicus and $M$. maculatus. This indicates that the number of bird species interacting with epiphytes may still be underestimated, and that studies involving different forest formations and stages of regeneration increase these numbers.

In conclusion, the presence of epiphytes is of great ecological importance for the environment and for birds, as they use the most varied resources such as water, nectar, seeds and invertebrates. These resources may be absent or few in a pasture environment. Thus, epiphytes are essential in these areas for maintaining various bird species. In addition, trees in the pasture can act as "stepping stones", and thus the epiphytes play an important role in providing resources for birds that are moving between fragments and continuous forest areas.

\section{ACKNOWLEDGEMENTS}

To CAPES for the scholarship. To the Federal Rural University of Rio de Janeiro and to the Graduate Program in Environmental and Forestry Sciences for hosting and teaching. To the owners of REGUA, Nicholas and Raquel and their employees for all their help and dedication in the development of this project.

\section{REFERENCES}

Antas P.T.Z. 2004. Pantanal: guia de aves. http://www.avespantanal. com.br/paginas/ index.htm (Access on 03 December 2013).

Azevedo A.D. 2012. Composição florística e estoque de carbono em áreas de recuperação da Mata Atlântica na Bacia do Rio Guapiaçu, Cachoeiras de Macacu, RJ. MSc. Dissertation. Rio de Janeiro: Universidade Federal Rural do Rio de Janeiro.

Barth B.J., Gibbon S.I.F \& Wilson R.S. 2015. New urban developments that retain more remnant trees have greater bird diversity. Landscape and Urban Planning 136: 122-129.

Benzing D.H. 1990. Vascular epiphytes. Cambridge: Cambridge University Press.

Canela M.B.F. \& Sazima M. 2003. Aechmea pectinata: a hummingbirddependent bromeliad with inconspicuous flowers from the rainforest in south-eastern Brazil. Annals of Botany 92: 731-737.

Cestari C. 2009. Epiphyte plants use by birds in Brazil. Oecologia Brasiliensis 13: 689-712.

Cestari C. \& Pizo M.A. 2008. Utilization of epiphytes by birds in a Brazilian Atlantic Forest. Ornitología Neotropical 19: 97-107.

Cruz-Angón A. \& Greenberg R. 2005. Are epiphytes important for birds in coffee plantations? An experimental assessment. Journal of Applied Ecology 42: 150-159.

Derroire G., Coe R. \& Healey J.R. 2016. Isolated trees as nuclei of 
regeneration in tropical pastures: testing the importance of nichebased and landscape factors. Journal of Vegetation Science 27: 679-691.

Fadini R.F. \& Marco-Jr. P. 2004. Interaçôes entre aves frugívoras e plantas em um fragmento de Mata Atlântica de Minas Gerais. Ararajuba 12: 97-103.

Gibbons P., Lindenmayer D.B., Fischer J., Manning A.D., Weinberg A., Seddon J., Ryan P. \& Barrett G. 2008. The future of scattered trees in agricultural landscapes. Conservation Biology 22: 13091319.

Groombridge B. 1992. Global biodiversity: status of the Earth's living resources. London: Chapman \& Hall.

Hasui E., Gomes V.S.M. \& Silva W.R. 2017. Effects of vegetation traits on habitat preferences of frugivorous birds in Atlantic Rain Forest. Biotropica 39: 502-509.

Ikuta K.G. \& Martins F.C. 2013. Interaçôes entre aves frugívoras e plantas no Parque Estadual da Cantareira, estado de São Paulo. Atualidades Ornitológicas 172: 33-36.

IBGE [Instituto Brasileiro de Geografia e Estatística]. 2009. Mapa da vegetação do Brasil. http://mapas.ibge.gov.br/tematicos/vegetacao (Access on 03 October 2016).

Jordano P., Galetti M., Pizo M.A. \& Silva W.R. 2006. Ligando frugivoria e dispersão de sementes à biologia da conservação, p. 411-436. In: Rocha C.F.D., Bergallo H.G., van Sluys M. \& Alves M.A.S. (eds.). Biologia da conservação: essências. São Carlos: RiMa.

Manning A.D., Fischer J. \& Lindenmayer D.B. 2006. Scattered trees are keystone structures implications for conservation. Biological Conservation 132: 311-321.

Martinelli G. 1997. Biologia reprodutiva de Bromeliaceae na Reserva Ecológica de Macaé de Cima, p. 213-250. In: Lima H.C. \& Guedes-Bruni R.R. (eds.). Serra de Macaé de Cima: diversidade florística e conservação em Mata Atlântica. Rio de Janeiro: Jardim Botânico do Rio de Janeiro.

Moga C.I., Samoilă C., Öllerer K., Băncillă R.I., Kinga-Olga R., Craioveanu C., Poszet S., Rákosy L. \& Hartel T. 2016. Environmental determinants of the old oaks in wood-pastures from a changing traditional social-ecological system of Romania. Ambio 45: 480-489.

Myers N., Mittermeier R.A., Mittermeier C.G., Fonseca G.A.B. \& Kent J. 2000. Biodiversity hotspots for conservation priorities. Nature 403: 853-858.

Nadkarni N.M. \& Matelson T.J. 1989. Bird use of epiphyte resources in Neotropical trees. Condor 91: 891-907.

Piacentini V.Q. \& Varassin I.G. 2007. Interaction network and the relationships between bromeliads and hummingbirds in an area of secondary Atlantic Rain Forest in southern Brazil. Journal of Tropical Ecology 23: 663-671.

Pizo M. A. 1994. Estudo comparado da dispersão e predação de sementes de Cabralea canjerana (Meliaceae) em duas áreas de mata do Estado de São Paulo. MSc. Dissertation. Campinas: Universidade Estadual de Campinas.

Pizo M.A. \& Santos B.T.P. 2011. Frugivory, post-feeding flights of frugivorous birds and the movement of seeds in a Brazilian fragmented landscape. Biotropica 43: 335-342.

Poltz K. \& Zotz G. 2011. Vascular epiphytes on isolated pasture trees along a rainfall gradient in the lowlands of Panamá. Biotropica 43: 165-172.

Prevedello J.A., Almeida-Gomes M. \& Lindenmayer D.B. 2018. The importance of scattered trees for biodiversity conservation: a global meta-analysis. Journal of Applied Ecology 55: 205-214.

Richards P.W. 1996. The Tropical Rain Forest: an ecological study. Cambridge: Cambridge University Press.

Rocha C.F.D., Cogliatti-Carvalho L., Nunes-Freitas A.F., RochaPessôa T.C., Dias A.S., Ariani C.V. \& Morgado L.N. 2004. Conservando uma larga porção da diversidade biológica através da conservaçáo de Bromeliaceae. Vidalia 2: 52-68.

Sandor M.E. \& Chazdon R.L. 2014. Remnant trees affect species composition but not structure of tropical second-growth forest. PLoS ONE 9: e83284.

Scheffers B.R., Edwards D.P., Diesmos A., Williams S.E. \& Evans T.A. 2014. Microhabitats reduce animal's exposure to climate extremes. Global Change Biology 20: 495-503.

Schlawin J.R. \& Zahawi R.A. 2008. "Nucleating" succession in recovering Neotropical Wet Forests: the legacy of remnant trees. Journal of Vegetation Science 19: 485-492.

Sheldon K.S. \& Nadkarni N.M. 2013. The use of pasture trees by birds in a tropical montane landscape in Monteverde, Costa Rica. Journal of Tropical Ecology 29: 459-462.

Sigrist T. 2009. Avifauna brasileira: pranchas e mapas. Vinhedo: Avis Brasilis.

Sillett T.S. 1994. Foraging ecology of epiphyte-searching insectivorous birds in Costa Rica. Condor 96: 863-877.

Wheelwright N.T, Haber W.A., Murray K.G. \& Guidon C. 1984. Tropical fruit-eating birds and their food plants: a survey of Costa Rican Lower Montane Forest. Biotropica 16: 173-192.

Zwiener V.P., Cardoso F.C.G., Padial A.A. \& Marques M.C.M. 2014. Disentangling the effects of facilitation on restoration of the Atlantic Forest. Basic and Applied Ecology 15: 34-41.

Associate Editor: Caio G. Machado. 